
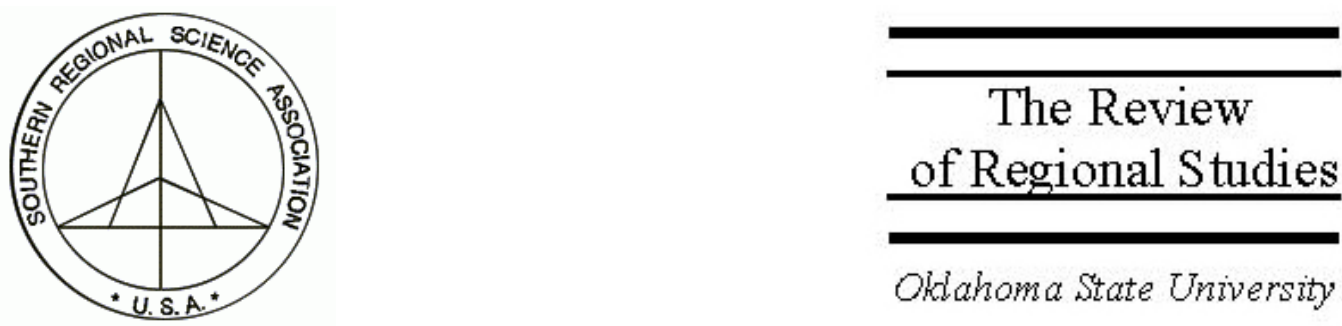

\title{
Speaking Falsehoods to Power: States’ Misguided Use of “Cost-of-Doing-Business” Studies in Economic Development Policy
}

\author{
Michael I. Luger \\ Manchester Business School, University of Manchester, UK, M15 6PB, e-mail: \\ michael.luger@mbs.ac.uk \\ Suho Bae \\ Public Administration Program, San Francisco State University, San Francisco, CA \\ 4132, e-mail: baes@rockinst.org
}

\begin{abstract}
Economic developers at the local and state levels have increasingly used cost-of-doing-business studies to compare their jurisdictions against others. The cost of doing business is enormously difficult to demonstrate in practice because: (1) there are many different types of business costs, many of which are difficult to measure; (2) in making their location choices, businesses take into account more than direct cost differences; and (3) businesses often behave in a dynamic way and either change how they operate to accommodate cost increases or accept some high costs if there are compensating lower costs or benefit payoffs in a particular location. This paper shows that the data and methods used in typical cost-of-doing-business studies are flawed and incomplete and therefore the implications of the studies are misleading.
\end{abstract}

Keywords: Cost-of-doing-business; Business recruitment; Retention policy

JEL classification: D83; H71; O18

The authors acknowledge Leslie Scott and Brande Roberts in the Carolina Center for Competitive Economies (C3E) for help in the design and administration of a survey of North Carolina Economic Developers' Association (NCEDA) members. Leslie Scott, Howard Chernick, and anonymous referees for this journal provided helpful comments on an earlier draft. 


\section{INTRODUCTION}

As economic development scholars and regional scientists, we would like to believe that the tax, regulatory, and subsidy decisions that affect businesses at the state level are guided by objective, careful analysis. ${ }^{1}$ Indeed, in many cases, our profession has succeeded in elevating the quality of economic development policy making. University-based research centers have successfully demonstrated how good applied research and analysis have informed—and even shaped-tax, employment and training, science and technology, infrastructure, and education policy.

However, in one large and important area of economic development policy, objective, rigorous, university-based research and analysis have had little impact. In "business recruitment and retention policy" there is considerably more darkness than light. For several reasons we detail below, the issues are "wicked" (to use Webber and Rittel's 1973 term) and defy simple analysis. The absence of "truth" attracts special interestsincluding some from within the economic development profession-whose hunch-based and hearsay-driven advice to decision makers crowds out rational and balanced analysis. There is even, arguably, intentional misrepresentation, or at least a willing acceptance of incomplete and misleading facts, which accounts for this paper's title.

The environment in which economic development professionals operate is inherently difficult. Data deficiencies and modeling limitations hamper efforts to connect policy to outcomes (what social scientists refer to as "the attribution problem"). Those who care about efficiency in the formulation and application of policy may be inclined toward caution. But there is considerable pressure on them to respond to the demands of businesses that increasingly play one jurisdiction off against another when they want to expand or relocate. (See Levy, 1990, pp. 11-17, for more detail.) The elected officials to whom the economic developers report (often county commissioners) want to be seen by their constituents as actively pursuing economic development. There is no more visible sign of success than to cut a ribbon on a new plant that provides a sizable number of wellpaying jobs. Accordingly, the decision-makers tend to measure the effectiveness of their economic development staff in terms of "new announcements," "new jobs created," and "value of new investment." This in turn spurs on what has been referred to as "the buffalo hunt," or “chasing smokestacks.” In Rubin's (1988, p. 237) words, economic developers are "shooting at everything that flies," using as large an arsenal of incentives as they can muster. That arguably results in business interests being served more than the public interest.

The uncritical use of business incentives is further encouraged by economic developers who believe that "working with and for businesses might provide a more effective

\footnotetext{
${ }^{1}$ Bartik (1994, 2005) argues that high-quality and rigorous evaluation of state and local economic development programs is essential for those programs to be effective and actually contribute to state and local economy growth.
} 
way of accomplishing something” (Rubin 1988, p. 246)—who believe, in other words, that their efforts to respond to business demands result in economic changes, while the "formalistic" or symbolic actions that governments and economic development boards engage in have little effect on local economy. Economic developers thus "act as a pressure group to provide incentives to the business community” (Rubin 1988, p. 249).

Site-selection consultants, working for such companies as Fluor Global Location Strategies, J.M. Mullis, DCG Corplan, AngelouEconomics, and Deloitte and Touche (see a roster at www.ecodevdirectory.com/siteselections.htm) further contribute to the proliferation of incentives. These companies have a vested stake in the buffalo hunt; they benefit from inter-local competition. Often, their compensation includes a percentage of the incentives that competition generates. For example, a recent Raleigh News \& Observer article stated the following.

Two years ago, North Carolina offered R.H. Donnelley Corp. \$4.3 million to move its headquarters to Cary. But the telephone book publisher didn't hold onto all of that money. A good chunk of it-as much as 20 percent-went to KPMG, the major accounting firm, and a former consultant, ... . [which] is part of a growing group of siteselection consultants that businesses hire to evaluate cities and states for a move or expansion. These consultants often determine which state is chosen and how much the state pays to get businesses here. Consultants say they make $\$ 50,000$ to $\$ 100,000$ on a typical six-month project if they charge a fixed fee. Compensation can reach into the hundreds of thousands of dollars for those whose fee is based on the value of incentives they negotiate along the way. . . .

Consultants' pay is stirring debate among North Carolina's economic developers. Critics of contingency fees argue that they encourage consultants to drive up the cost of incentives beyond what's necessary to get businesses here. What's more, critics think, consultants working on contingency fees are less likely to steer businesses toward places with few or no incentives, even if those places have plenty else to offer, such as a qualified work force and low tax burden. (Martinez, 2005, p. A1)

Here again, self-interest can outweigh public interest. For site selection consultants as well as economic developers, "cost-of-doing-business" studies become the deus ex machina - the vehicle that demonstrates why more incentives are justified.

\subsection{The Nature of the Beast}

We characterized business recruitment and retention as a particularly "wicked" area of policy. In short, it is very difficult to know to what extent businesses respond to tax, regulatory, and subsidy programs. There is no typical business. Different industries have different cost structures, and businesses differ in their ability to change their behavior to 
avoid business costs. In addition, outcomes in any one jurisdiction depend not only on exogenous market conditions, but also on the level and type of taxes, regulations, and subsidies in all competing jurisdictions. Even if we had all the data needed to calculate relative costs of doing business, we would be hard-pressed to connect observed outcomes to policy differences. "Attribution" is a particular challenge in this context.

This sobering conclusion is not ours alone. It is the concern of virtually all thoughtful regional economists who have studied the topic, as evidenced by the proceedings of a 1997 Boston Fed symposium entitled "The Effects of State and Local Public Policies on Economic Development.” In the case of tax incentives, for example, Bradbury, Kodrzycki, and Tannenwald (1997, pp. 3-4) observe that "researchers have had difficulty determining the degree to which employment, investment, or business location responds to differences in state and local taxes . . . [M]uch of the uncertainty is attributable to measurement and definition issues.” Fisher (1997) concludes much the same about the effect of public services on location. And, in the case of regulatory policy, Tannenwald (1997, p. 84) argues that the two-sided effects of regulation-adding costs for compliance on the one hand, but improving the quality of life as a consequence on the other"complicate the task of evaluating the net impact of regulation on economic development." Despite the wickedness of the issue, cost-of-doing-business studies play a prominent role in economic development policy.

\subsection{How Location Decisions and Incentive Policy are Made}

The "business location" stakeholders to whom we refer here include local economic developers, site-selection consultants, businesses themselves, and state and local policy makers. Increasingly, location decisions are made by businesses based on their own analysis and/or advice from paid site-selection consultants. They use generally available information, including cost-of-doing-business studies, magazine rankings (the "best places” ratings), personal preferences (where the surfing is good!), and other anecdotal information (including what is put on local governments' Web sites) to construct a shortlist of candidate locations. At that point, they may ask the short-list of places to provide more detailed information (even to the extent of responding to a request for proposals), which they process behind closed doors. Neither the data nor the basis for the decision is typically ever made public. Moreover, the public incentives put on the table are considered proprietary in most states, even after the deal is concluded. ${ }^{2}$

\footnotetext{
${ }^{2}$ There is mounting pressure for states to change this. For example, a recently introduced North Carolina bill would require disclosure of an incentive deals' terms after the deal is concluded (see Curliss 2005). The discussion in this section elaborates/updates the business location dynamic as described by Moriarty (1980); Schmenner (1982); Schmenner, Huber, and Cook, (1987), inter alia. They point out that business location is characterized as a multi-stage process in which firms select several candidate regions, search candidate locations in these selected regions, and select the best (for them) location. In each stage, firms consider specific location factors. We agree that business location is a multi-stage process, but we stress its dynamic nature. Modern businesses are less likely to search candidate locations after several regions are selected. They are more likely to search candidate locations at the same time that they are looking for candidate regions.
} 
This process has numerous weak links. The local economic developers desperately want to lure the buffaloes - perhaps today more than ever, given the high rate of job loss many places have experienced. But since they have increasingly little interaction with businesses throughout the process, they do not know what they really value. ${ }^{3}$ Winners, of course, are delighted, but they never are told how important the incentives they put forward really were. Rather, they are always led to believe that the last dollar was the deal clincher (Dewar 1998). Losers are sometimes debriefed after the decision has been made, but rarely in a detailed way. They never really know, then, whether it was their incentive package or other fundamentals. Since it is harder to change local wages, workforce quality, or land prices in the short-run, it is tempting to blame the loss on the uncompetitiveness of the state-local incentive package.

The business decision-makers, and site-selection consultants whom they may retain, are challenged by the complicated (wicked) nature of the location problem. Corporate accountants use the information they have been provided to estimate the bottom line in different locations. But, as we explain below, the data and modeling requirements to do that accurately are beyond the ability of most, if not all, businesses (and academics).

State and local policy-makers are as confused as anyone. In recent years, in particular, they have seen plants close and move off-shore and have heard about the prize catch by the jurisdiction next door, and they want to know why their home towns are not more successful. There is no good information coming forth from businesses or site-selection consultants, and their own staffs lack the capacity to do the detailed and complicated analysis required to answer the question.

This is the gap that cost-of-doing-business studies are used to fill. The studies we include in this category (which we characterize more fully below) were not necessarily designed to be used as broadly as they sometimes are. But economic developers and policy makers both put an inflated value on them as a means to help them understand why places win and lose. Economic developers are tempted to use them as grounds for more business-friendly incentives. And legislators turn to them as seemingly objective sources to help them understand how their jurisdiction stacks up against the competition. If the studies were indeed well executed and complete, site-selection consultants would be less in demand. But, given the nature of the beast, they have nothing to fear.

The confusion that prevails about the real costs of doing business may serve the interests of site-selection consultants, but it works against the public interest. It feeds what has been derisively called "the race to the bottom," as a contagion effect drives taxes down and incentives up everywhere. ${ }^{4}$ Harley Duncan reaches a similar conclusion in a 1992 paper entitled "Interstate Tax Competition: The Good, The Bad, and The Ugly.” A

\footnotetext{
${ }^{3}$ An economic developer makes this same point during his interview with Rubin (1988).

${ }^{4}$ As Schweke, Rist, and Dabson (1994, pp. 32-33) also point out, one important reason why states employ development incentives for business recruitment and retention in their jurisdictions is inter-jurisdictional competition under the federal system.
} 
few states compete not on individual incentives but on general tax levels (the "good"). Others compete on the basis of tax incentives whose effects are difficult to predict and hard to track, inevitably leading to unintended distortions (the "bad"). Still others readily engage in a full-fledged bidding war, throwing everything but the kitchen sink into the inducement bucket (the "ugly”).

In the remainder of this article, we elaborate on the themes introduced above. We set the stage for our critique by reviewing the dynamics of business location. In order to understand the weaknesses in the cost-of-doing-business studies that are used in economic development, we need to understand the factors that drive location behavior. We follow that with information about how economic developers undertake comparative cost studies: by themselves or by hiring consultants, and if the latter, whom? For that, we rely on results from a survey we administered to members of the North Carolina Economic Developers' Association (NCEDA). We then provide a systematic critique of existing cost studies, leading us to conclude that they do more damage than good not only to businesses and policy-makers who are led astray, but also to the good name of the policy analysis profession. ${ }^{5}$ We conclude by asking two questions: who is to blame- - the economic developers who commission and use the studies or the so-called "experts" who produce them, or both? And, if the situation is so bleak, what can we do to make it better?

\section{WHAT DRIVES BUSINESS LOCATION/EXPANSION? A BRIEF REVIEW}

For a rational firm that seeks to maximize its profits or minimize its costs with a given level of output, it is fair to conclude that the cost of doing business is a major consideration in deciding where to locate or expand facilities. That seemingly simple proposition is enormously difficult to demonstrate in practice, however, because of three complications: (1) there are many different types of business costs, many of which are difficult to measure; (2) in making their location choices, businesses take into account more than direct cost differences; and (3) businesses often behave in a dynamic way and either change how they operate to accommodate cost increases or accept some high costs if there are compensating lower costs or benefit payoffs in a particular location.

\footnotetext{
${ }^{5}$ Connaughton and Madsen (2001) select the two economic impact studies done for the BMW assembly plant in South Carolina and the Mercedes-Benz assembly plant in Alabama (South Carolina State Development Board, 1992; and Homles and McCallum, 1993) and argue that their methodologies, including their use of multipliers, are inappropriate and that their economic impacts are overestimated. They also point out that these studies were used to justify large economic incentive packages bid by South Carolina and Alabama. Their claim is similar to our paper's argument that (1) current cost-of-doing-business studies are used for economic developers to justify requiring more incentives from state governments, and (2) their methods are flawed and incomplete and their results therefore misleading.
} 


\subsection{Many Types of Costs}

Calculating the cost of doing business is a formidable task because there are so many types of costs, and many of those costs vary among businesses even within the same industry. The costs normally compared are for labor, land, utilities, state and local taxes, and regulatory requirements (omitting capital, because it is believed to be more mobile and uniformly priced). ${ }^{6}$ Cost-of-doing-business studies often include taxes, but not fees and charges, which is a problem we come back to later.

Labor and land costs and tax rate differentials are commonly included in econometric studies of business location (see, for example, Carlton 1983; Luger and Shetty 1985; Papke 1991; Hines 1996; Coughlin and Segev 2000 for reviews). Most studies use the manufacturing wage rate as the indicator of labor costs; Bartik (1985) uses states' unionization rates as his measure and finds that they negatively affect business location. Few studies include non-wage compensation as part of labor costs, even though benefits are likely to vary considerably across states (see Yates and Burton 2004-another problem to which we return.) Other researchers hypothesize that heavy regulatory burdens represent efficiency losses for firms and, hence, disincentives to locate. For example, Jaffe et al. (1995) and Gray (1997) find that strict environmental regulations pose a greater disadvantage to new manufacturing businesses than to existing ones, and that states with strict regulations tend unwittingly to discourage formation of new plants, other things being equal (see also Jeppesen, List, and Folmer 2002 for a review).

The cost of doing business is also affected by the presence of subsidies and of tax incentive programs that effectively reduce businesses' tax rate. ${ }^{7}$ Dozens of studies published mostly in regional and urban economics, regional science, public policy, planning, and geography journals attempt to connect government business incentives to location behavior. (Luger and Bae, 2005, provide a review of some that literature. ${ }^{8}$ )

\footnotetext{
${ }^{6}$ Luger and Bae (2002) argue that location studies generally disregard infrastructure cost and availability differences.

${ }^{7}$ There are two different theoretical views on why local governments use tax incentives and subsidies to attract new plants to their jurisdictions. The first view holds that tax incentives and subsidies can enhance the welfare of local residents through the contributions of new plant location to agglomeration economies, increases in producer surplus, or future expropriation. The second view, by contrast, holds that they can decrease the welfare of residents because government officials may maximize their private interests or the size of government. For more details, see Glaeser (2001) and Greenstone and Moretti (2003).

${ }^{8}$ A survey by POLICOM (2001, p. 2) identifies the four most prevalent local government business incentive programs: tax abatements, low interest rate loans, grants or gifts, and discounts on local fees. These are used, according to the survey, to (1) "reduce the initial setup costs for a company in a community," (2) "reduce the long-term operating costs for a company," (3) "project a business friendly image to potential companies," (4) "encourage economic or real estate development in blighted areas," (5) "overcome geographic disincentives for an area," and (6) "overcome self-inflicted disincentives for an area."
} 


\subsection{Other Location Factors Indirectly or Not Related to Costs}

Direct business costs (and cost-savings), however, are not the only factors driving firms' location behavior; non-cost factors (or attributes of a place that only affect costs indirectly) are also important, if to varying degrees, among different types of businesses. According to Reese and Rosenfeld (2001), businesses may be more concerned about the overall health of the local community rather than about large tax and financial incentives to lower business costs, for example. Perceived business climate (often a euphemism for "business-friendly regulations and policies" but having broader, symbolic importance), a region's quality of life (including environmental quality), and non-business costs (such as the local cost of living and individual tax rates and rules) are also important.

Amenities and quality-of-life considerations can affect a business's bottom line differently in different places and hence influence where that business chooses to locate. But they show up in other ways as well. There are two theories about how amenities can influence business location decisions (Gottlieb 1994). First, amenities can tilt the scale toward areas that, according to numbers alone, are not the most profitable among the contenders. Second, managers may have an easier time recruiting and retaining workers, especially those with higher skills, to amenity-rich areas and may even be able to pay them less than they would have to if the area had fewer amenities.

The quality of K-12 schools, for example, is an important amenity in location decisions, since knowledge workers in high-tech businesses want to live where their children can be well educated (Jarboe 2001; Gabe and Bell 2004). Poor air quality can cause an area to be designated as "non-attainment" by the EPA, making permits for new construction hard to obtain. Rich (1997, p. 74) argues that quality-of-life factors are becoming more prominent in business location decisions because of "decentralization of corporate decision making, spinning off of clusters of related companies, and ascendancy of smaller businesses. As more communities offer the same incentives, those incentives lose their power, and there is less emphasis on deal making and more on those unique features that distinguish a community from its competitors.” (See also Gottlieb 1994; Johnson and Rasker 1995; Luger 1996; and Segedy 1997.)

Many studies emphasize the importance of other attributes that are only indirectly related to costs. Love and Crompton (1999) focus on climate and weather, proximity to colleges or universities, the quality of primary and secondary education, low crime rates, and local recreation opportunities. Recent work by Richard Florida (2002) underscores the importance of non-cost factors in the attraction of a "creative class" of workers (those who work in creative businesses). According to Florida, they seek locations that are culturally diverse and replete with such amenities as coffee houses, live music, and recreation.

Finally, a growing literature focuses on the importance of agglomerations of various types (including, most recently, business "clusters") as a location inducement because of 
the external economies they generate. ${ }^{9}$ Businesses that co-locate can trade market information, tap into the same pool of inputs (for example, labor, infrastructure, and services), and learn more quickly about technological advances. According to Porter (2000, p. 24), "Firms within a cluster can experiment at lower cost or delay large commitments until there is greater assurance that a new product, process, or service will pan out. By contrast, a firm relying on distant outsourcing faces greater challenges of contracting, securing delivery, obtaining associated technical and service support, and coordinating across complementary entities." 10 But the effect of agglomeration on location is not the same for all types of businesses. For example, Carlton (1983) finds that the relative importance of agglomeration economies in industrial location is greater in an industry with small-sized plants than in an industry with large-sized plants.

\subsection{Business Decision-Making is Typically Dynamic}

The analysis of how business costs affect location is complicated by the dynamic nature of business decision-making. One type of dynamic solution to the question of location is to change factor use in response to changing prices. Faced with new or continuing location in a high-wage area, for example, a business could either search for an alternative location with lower wages or, more likely, substitute capital. We would then expect to observe businesses in the same industry but in different locations having different capital-to-labor ratios (see Luger and Evans 1988).

Offsetting effects and compensating differentials also play an important role in location decisions. Offsetting effects occur when businesses decide not to move in response to one kind of high cost in a location because of compensating lower costs there. For example, a business might accept higher wage rates demanded by workers in a jurisdiction if that jurisdiction has cheaper land or lower utility costs. Blair and Premus (1993, p. 13) argue the converse: firms located in high personal income tax states or in local jurisdictions with high personal property taxes could respond by offering workers higher wages as a retention strategy, rather than moving. "Compensating differentials" refer to the presence of benefits in a location that justify a business's greater outlay on inputs, including taxes. Analyzing business location and investment data at the municipality level in Maine, Gabe and Bell (2004) found that low spending on public goods and services, followed by low local taxes, led to less business investment than high spending with high local taxes. (Luger, 1996, provides a review of that literature; see also Tiebout's 1956 argument about the trade-off between taxes and benefits in the location decision.) The presence of net benefits for location in a particular place, relative to

${ }^{9}$ See, for example, Carlton (1983); Bartik (1985); Coughlin, Terza, and Arromdee (1991); Mani, Pargal, and Huq (1996); Carod (2002); Gabe and Bell (2004). In addition, Gordon and McCann (2000) explain distinct characteristics of spatial clustering from three different perspectives: pure agglomeration, industrial complex, and social network.

${ }_{10}$ According to Blair and Premus (1993, p. 17), "Some agglomeration economies reflect the cost advantages of consolidating operations of a firm at one facility by locating a cluster of plants near each other. Firms that buy and sell with each other may benefit from less specific agglomeration economies through reduced transportation and negotiation costs.” 
alternative locations, should also generate capitalization effects, driving up land values and costs at the favored site.

Much of the foregoing discussion about the determinants of business location/ expansion is summarized in Figure 1.

As we have seen, differences in regulatory environments, other local characteristics, amenities and quality of life, and cost of living affect the standard factors used in cost-ofbusiness studies (i.e., wages, land prices, tax costs, tax incentives, and compliance costs), but they have other consequences for business location/expansion as well. The outcome of the business location/expansion decision then feeds back into the value of the variables that will affect future location/expansion decisions in a local jurisdiction. In short, the business location/expansion decision is really dynamic in a local setting.

\section{HOW DO ECONOMIC DEVELOPERS JUDGE THE COMPETITIVENESS OF THEIR JURISDICTIONS?}

How do economic developers make comparative judgments about their jurisdiction's costs of doing business versus other jurisdictions? On what kinds of information do they rely? To answer these questions, we collected information through a survey of North Carolina Economic Developers' Association (NCEDA) members. NCEDA is a professional membership organization consisting of local economic development and chamber of commerce officials, builders, bankers, and other economic development "allies" from all over North Carolina. ${ }^{11}$ We sent out two waves of e-mail surveys to one member of the Association from each of 100 counties in North Carolina, plus three officers at the state level. (See appendix for the survey.) We received 16 valid responses from the total sample size of 103, a response rate of about 16 percent, which is consistent with recent national experience for e-mail surveys of this type (Renault 2003). Because of the small number of responses, we do not push the results too far; rather, we view them as preliminary and suggestive, to be verified in later work.

Table 1 shows the distribution of survey responses to the question "How important is each information source to you in making comparative judgments about your jurisdiction's costs of doing business versus other jurisdictions?” Most respondents cited their own analyses as being the most important source, followed by place-specific analyses and what they learn from site-selection consultants after the location decision have been made. This is the pattern we should expect, since local economic developers typically work from very specific requests for information from a business or a site-selection consultant, which requires research on costs locally and in competing places. When asked why they did not rely more on outside consultants and business location officials for cost-of-doing-business comparisons before the location choice is made, one respondent said that "consultants and business executives [are] very hesitant to pass on this type of information. Also it is not comprehensive and doesn't allow for comparison with a

11 “Allies” refers to utility companies and service providers such as law firms. 


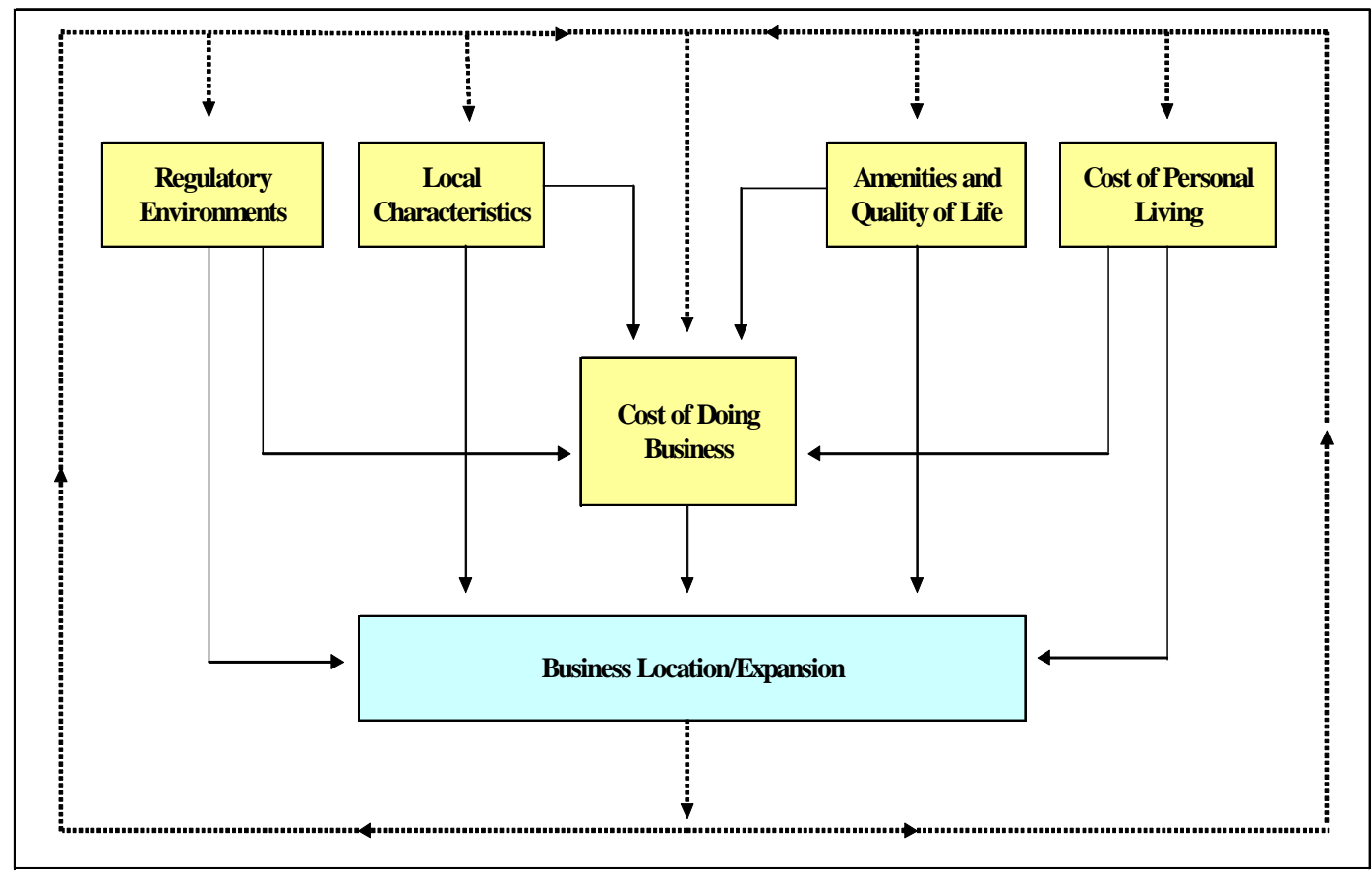

Note: Solid lines represent direct effects, while dotted lines represent feedback effects.

FIGURE 1. Business Location/Expansion in a Local Jurisdiction

TABLE 1

Information Sources on Cost-of-Doing-Business

\begin{tabular}{|c|c|c|c|c|c|c|}
\hline \multirow{2}{*}{ Information Source } & \multicolumn{5}{|c|}{ Scale } & \multirow{2}{*}{ Tota } \\
\hline & 1 & 2 & 3 & 4 & 5 & \\
\hline Your own research and number crunching. & 11 & 3 & 2 & 0 & 0 & 16 \\
\hline $\begin{array}{l}\text { Information about the costs of your and other } \\
\text { locations that you learn from site selection } \\
\text { consultants or business executives during the } \\
\text { selection process. }\end{array}$ & 1 & 3 & 8 & 3 & 1 & 16 \\
\hline $\begin{array}{l}\text { Information about cost factors that you get in "de- } \\
\text { briefings" from site selection consultants or business } \\
\text { executives after the site location decision is made. }\end{array}$ & 1 & 8 & 4 & 2 & 1 & 16 \\
\hline $\begin{array}{l}\text { Written reports or studies with data on place-specific } \\
\text { cost comparisons. }\end{array}$ & 4 & 5 & 5 & 1 & 1 & 16 \\
\hline
\end{tabular}


large number of communities." Another respondent stressed that "experts' analyses have to be looked at very carefully... [to make sure] they are credible." Yet another respondent said: "It's not that the reports are inaccurate, it's that they may use a variety of unknown factors to make their rankings or that I may disagree with the standardized data that they use.”

These comments suggest that economic developers cared about (or knew how to conduct) high-quality cost comparisons, but that is not uniformly true. Nor is it necessarily relevant. In fact, in most cases, economic developers care less about doing a "study" than they do about responding quickly (sometimes in 48 or 72 hours) to a request for information from a prospect. For that purpose, standard data from the Bureau of Labor Statistics (BLS), Bureau of Economic Analysis (BEA), state employment security commissions, and state departments of commerce, for example, are considered sufficient. Those are good sources, but: (1) they do not provide all the detailed information that is requested; and (2) if data are not provided in the same way for all competing jurisdictions, it is difficult to make judgments across competing communities. To address these problems, the International Economic Development Council (IEDC) has developed a template for all jurisdictions to use that includes consistent, detailed data, not only from the standard sources listed above, but also from surveys of local utility companies and municipal departments. That approach holds promise as a way to advance the state of the art, but is not fully implemented yet.

\section{CRITIQUE OF COST-OF-DOING-BUSINESS STUDIES}

As previously noted, economic developers at the local and state levels have increasingly used cost-of-doing-business studies to compare their jurisdictions against others, either to demonstrate competitive advantages for their jurisdictions or to demonstrate to legislators how costly and uncompetitive they are. This development reinforces Rubin's (1990) finding that as the economic condition of their communities becomes more turbulent and less certain, economic developers tend to take more symbolic actions (such as mass advertising and describing their communities in glowing terms) or implement economic development policies redistributing wealth to the business community (such as excessive incentives to current businesses).

Table 2 lists several studies that were identified to us in the literature and from survey respondents as widely used and typical of cost-of-doing-business analyses. In this section, we provide a critique of those studies. We show that the data and methods they employ are flawed and incomplete. Accordingly, their results are misleading.

The Ernst \& Young, West Virginia, and Pennsylvania Economy League studies (the first three listed in Table 2) focus on taxes and tax incentives and will be considered together. 
TABLE 2

Selected Cost-of-Doing-Business Studies

\begin{tabular}{llc}
\hline Author & \multicolumn{1}{c}{ Title } & $\begin{array}{c}\text { Unit of } \\
\text { Analysis }\end{array}$ \\
\hline Ernst \& Young & $\begin{array}{l}\text { State of North Carolina Comparative } \\
\text { Incentives Study }\end{array}$ & State \\
$\begin{array}{l}\text { W.V. Dept. of Tax \& Revenue and } \\
\text { W.V. Development Office }\end{array}$ & $\begin{array}{l}\text { Analysis and Recommendations for } \\
\text { West Virginia Tax Incentives }\end{array}$ & State \\
Pennsylvania Economy League & $\begin{array}{l}\text { A Comparative Analysis of Major } \\
\text { State Business Taxes in Pennsylvania } \\
\text { and Other State }\end{array}$ & State \\
Economy.com & $\begin{array}{l}\text { United States Business Cost Review } \\
\text { Fisher and Peters }\end{array}$ & State/MSA \\
& $\begin{array}{l}\text { Industrial Incentives: Competition } \\
\text { Among American States and Cities }\end{array}$ & State/City \\
Economist Intelligence Unit & $\begin{array}{l}\text { Worldwide Business Cost } \\
\text { Comparisons: The Cost of Setting Up } \\
\text { Business in 31 Countries }\end{array}$ & Country \\
KPMG & Competitive Alternatives & Country/City \\
POLICOM & Economic Strength Ranking & MSA \\
DeVol and Fogelbach (Milken & Best Performing Cities: Where \\
Institute) & America’s Jobs are Created & MSA \\
ACCRA & Cost of Living Index & MSA \\
\hline
\end{tabular}

We asked several questions when assessing the quality of the studies, including the following: (1) In calculating the cost of doing business, did the studies include all relevant costs, such as described in section 2 above? (2) Did they consider non-cost factors, as shown in Figure 1, including regulatory environment, amenities and quality of life, local characteristics, and cost of living? Did they account for the effects of those factors indirectly as well as directly on business location/expansion decision? (3) Did they account for jurisdiction-to-jurisdiction variation within states and differences among types of businesses (by industry) in cost structure? And (4) did they consider the feedback effects of business location/expansion in a local jurisdiction on both cost and noncost location factors? In other words, did they account for dynamic patterns under a framework of general equilibrium in comparing costs of doing business across different jurisdictions? 


\subsection{The Tax and Tax Incentives Studies (from Ernst \& Young, Pennsylvania Economy League, and West Virginia)}

These studies have all been used to convince state legislators that their states are not competitive in the buffalo hunt because of high taxes and/or low incentives. Each compares a client state against several other comparison states.

The Ernst \& Young study compares tax liabilities in seven states, using five sample industries. $^{12}$ The tax liabilities are meant to reflect statutory tax rates and existing incentive programs. The Pennsylvania Economy League's study chooses nine states similar to Pennsylvania in terms of industry mix, size, and location. ${ }^{13}$ In order to compare tax burdens across states, the League calculates tax collections per employee in each state-such as total business tax collections per employee, corporate net income tax collections per employee, capital tax collections per employee, and insurance premium tax collections per employee. In addition, business tax burden is measured as the portion of total business tax collections in total tax collections for each state. The West Virginia study, jointly conducted by the West Virginia Department of Tax and Revenue and the West Virginia Development Office, calculates state business tax liabilities across eight states for six industries, based on Risk Management Association (RMA) common-sized financial statements. ${ }^{14}$

None of the studies is comprehensive in terms of what costs are included. Indeed, their implicit and critical assumption is that businesses shop among states based only on post-incentive effective tax rates. Costs of labor, land, infrastructure services, energy, and regulatory compliance are not included. Neither are user fees and charges. The studies also make only state-to-state comparisons, assuming away differences among local jurisdictions within states. Differences in property tax rates, local options taxes, and user fees and charges on one side of the balance sheet and in amenities and quality of life, costs of living, agglomeration economies, and local incentives on the other side can be significant. In short, a very attractive community in an otherwise uncompetitive state may be a better location for a business than a high-tax, low-amenity community in an otherwise competitive state. Two of the studies (Ernst \& Young and West Virginia) use sample industries, rather than aggregate business, in the analysis.

The studies also ignore the possibility of dynamic behavior-adjustments in factor use in response to high costs and the presence of compensating differentials. To include

12 The five industries are automotive components, chemicals, data processing, information technology, and transportation equipment. The seven states are Alabama, Georgia, Kentucky, North Carolina, South Carolina, Tennessee, and Virginia.

${ }^{13}$ They are Florida, Illinois, Indiana, Massachusetts, Michigan, New Jersey, New York, North Carolina, Ohio, and Virginia.

${ }^{14}$ The eight states are Kentucky, Idaho, Maryland, North Carolina, Ohio, Pennsylvania, Virginia, and West Virginia. The six industries are motor vehicle parts \& accessories (SIC 3714), machine shops (SIC 3599), computer data processing (SIC 7374), computer-integrated design (SIC 7373), commercial, physical \& biological research (SIC 8731), and hotels and motels (SIC 7011). 
the first of these, the analysts would have to employ a dynamic general equilibrium model, which is beyond their technical capacity. To include the latter would require the inclusion of a much broader set of costs.

\subsection{Economy.com's Study}

United States Business Cost Review, conducted and marketed by Economy.com, calculates business cost indices for labor, energy, and state and local taxes. Then it ranks states and MSAs along each separate dimension as well as overall. To combine labor, energy, and taxes into a single index, Economy.com ascribes weights to each of 0.75 , 0.15 , and 0.1 , respectively.

Because the indices are constructed in the same way each year, they can be used to track changes in a state's or MSA's relative position over time, at least for the state or MSA as a whole and against a limited set of metrics. The approach is more comprehensive than the three critiqued above, since it includes more than taxes and tax incentives. But it still omits important factors, including non-wage compensation, the cost of transportation, infrastructure services, regulations, user fees and charges, and non-tax incentives. Moreover, the study does not take into account variations in business costs across localities in each state or across different industries.

Like the three studies discussed already, Economy.com considers neither non-cost factors nor the dynamic interactions among cost and non-cost factors. That can lead to very misleading results. A state may be shown to have fallen over time relative to others when, in fact, its business climate, quality of life, and level of amenities have improved dramatically. For example, state and local tax increases could be funding improvements in education, recreation, and culture. In addition, higher unit labor costs could indicate higher productivity and/or a shift in the state from lower-skilled to higher-skilled labor. That may, indeed, make that state less competitive for lower-skilled, lower-paying businesses but not for higher-tech employers who value the better quality of life and amenities. That sort of industrial transformation is the very goal of economic development in the U.S.

The use of weights in this and similar studies that construct and then aggregate indices presents a further problem. Economy.com based the $0.75,0.15$, and 0.1 weights for labor, energy, and taxes on national averages of the proportion of those elements in businesses' total costs. But those proportions differ by type of business and geographic location. The differences among businesses are shown in Table 3.

Some industries are more labor intensive (retail bakeries), while others are more capital intensive (inorganic dye and pigment manufacturing). And some use more energy (inorganic dye and pigment manufacturing) than others (electric housewares and household fan manufacturing). Transportation costs, though not shown in the table, affect some industries more than others-for example, those that produce goods and 
TABLE 3

Cost Structures for Selected Manufacturing Industries, 2001

\begin{tabular}{|c|c|c|c|c|c|c|}
\hline $\begin{array}{l}\text { NAISC } \\
\text { Code }\end{array}$ & Industry & $\begin{array}{c}\text { Labor } \\
(\%)\end{array}$ & $\begin{array}{l}\text { Machinery and } \\
\text { Equipment (\%) }\end{array}$ & $\begin{array}{c}\text { Buildings and Other } \\
\text { Structures (\%) } \\
\end{array}$ & $\begin{array}{c}\text { Materials } \\
(\%)\end{array}$ & $\begin{array}{c}\text { Energy } \\
(\%)\end{array}$ \\
\hline 311 & Food manufacturing & 12.2 & 2.1 & 0.5 & 55.6 & 1.7 \\
\hline 3118 & Bakeries and tortilla manufacturing & 23.9 & 2.9 & 0.6 & 33.7 & 1.5 \\
\hline 31181 & Bread and bakery product manufacturing & 28.2 & 2.9 & 0.7 & 31.4 & 1.6 \\
\hline 311811 & Retail bakeries & 38.5 & 4.2 & 1.0 & 32.9 & 1.7 \\
\hline 325 & Chemical manufacturing & 12.5 & 3.5 & 0.8 & 44.4 & 3.7 \\
\hline 3251 & Basic chemical manufacturing & 12.9 & 5.0 & 0.3 & 54.4 & 8.8 \\
\hline 32513 & Dye and pigment manufacturing & 17.1 & 5.0 & 0.5 & 48.7 & 6.2 \\
\hline 325131 & Inorganic dye and pigment manufacturing & 16.0 & 6.0 & 0.6 & 44.8 & 8.5 \\
\hline 335 & $\begin{array}{l}\text { Electrical equipment, appliance, and } \\
\text { component manufacturing }\end{array}$ & 21.8 & 2.6 & 0.3 & 49.1 & 1.0 \\
\hline 3352 & Household appliance manufacturing & 18.4 & 2.6 & 0.2 & 56.0 & 0.8 \\
\hline 33521 & Small electrical appliance manufacturing & 17.5 & 2.3 & 0.4 & 49.9 & 0.8 \\
\hline 335211 & $\begin{array}{l}\text { Electric housewares and household fan } \\
\text { manufacturing }\end{array}$ & 16.0 & 1.4 & 0.3 & 47.1 & 0.9 \\
\hline
\end{tabular}


services for export will be more sensitive to transportation costs than those that produce goods and services for local consumption.

\subsection{The Fisher and Peters' Tax and Incentive Model (TAIM)}

Fisher and Peters (1999) developed the Tax and Incentive Model (TAIM) to measure the impact on the return on firm investment of different types and amounts of incentives offered to manufacturing firms by state and local governments. To do so they constructed financial statements for 16 different typical, hypothetical firms (a large one and a small one from each of eight fast-growing manufacturing industries). ${ }^{15}$ They randomly selected 112 cities from the 24 states that account for a large proportion of the country's manufacturing employment.

The model is more complete than the other studies we have discussed. It includes taxes (federal income taxes, each state's and city's corporate income and net worth taxes, and the major state and local sales and property taxes paid by business), tax incentives (such as state corporate income tax credits for investment or job creation and local property tax abatements), and non-tax incentives (such as all major state and city grants, loans, loan guarantees and subsidies, linked deposits, and tax increment financing instruments). It allows for jurisdiction-to-jurisdiction variations within states and for differences in cost structure among large and small businesses within different industries.

To capture the full effects of incentives, the model is then applied to the sample firms and is simulated to derive a set of city-state firm-specific estimates of the impact of various provisions of the tax code on the return on firm investment over a 20-year period. The difference between returns on investment with incentives and returns on investment without incentives represents the value to the firm of the incentives offered.

While this model takes into account most of the taxes, tax incentives, and non-tax incentives at different levels of government, it assumes away other types of cost differences among firms within an industry and across cities and states (for example, wage and non-wage compensation, land costs, and energy costs). Like the four studies already discussed, it accounts for neither non-cost factors nor dynamic interactions among cost and non-cost factors. Because it estimates the magnitude of how businesses would respond to different types of incentives, the Tax and Incentive Model is useful in understanding the effectiveness of each type of incentive offered by different

15 They are furniture and fixtures, drugs, soaps, plastics, industrial machinery, electronics, autos/auto parts, and instruments. See Fisher and Peters (1999) for more details on how to construct the model. 
jurisdictions on firm investment under a static setting. ${ }^{16}$ However, it still provides a partial picture of the overall competitiveness of a jurisdiction against other competing jurisdictions in a more dynamic setting.

\subsection{Economist Intelligence Unit's Study}

Worldwide Business Cost Comparisons, by the Economist Intelligence Unit, is an international analog to the Economy.com study. It compares the cost of doing business in 31 countries, focusing on eight categories (the weights are shown in parentheses): wages and salaries (0.55), expatriate staff costs (0.03), business travel costs (0.03), corporation tax (0.11), corruption (0.04), office and industrial rents $(0.18)$, telecommunications (0.03), and road transport (0.03). Expatriate staff costs are essentially a cost-of-living index for major employment sites, including day-to-day living expenses, housing costs, and school costs. The corruption measure has elements of what we identified in Section 2 as regulatory costs.

By including eight versus three categories, or just taxes and incentives, this study is more comprehensive than the others reviewed so far (with the exception of Fisher and Peters' TAIM approach). But it still misses important business cost factors such as land, materials, other types of taxes (except on corporate income), user fees and charges, and tax and financial incentives. The study completely ignores non-cost factors and dynamic characteristics.

Most problematic is the high level of aggregation. For example, the study takes into account corporate tax rates at the national level and average rates at the state/sub-national level, but not the variations of corporate tax rates across states or sub-national units. It also uses national average wage rates, energy and infrastructure costs, and so on. Even developing countries have large variations among places in these cost factors. Also, because the study is not specific for different industries (or even sectors), it would be of limited use to businesses seeking locations because cost factors affect different kinds of businesses in different ways.

\subsection{The KPMG Study}

KPMG's (now BearingPoint's) Competitive Alternatives is as comprehensive and thorough as the Fisher and Peters study. It factors in costs for labor, office leasing or

\footnotetext{
${ }^{16}$ Fisher and Peters (1999) also used the TAIM model in analyzing the impacts of six economic development programs in Ohio: (1) Machinery \& Equipment Tax Credit Program (M\&E), (2) Job Creation Tax Authority Program (JCTC), (3) Ohio 166 Direct Loan Program, (4) Roadwork Development Grant Program, (5) Ohio Industrial Jobs Training Program, and (6) 412 Business Development Grant Program. To do so, they have selected 25 sites (five in Ohio and 20 in 10 competing states: Indiana, Kentucky, Michigan, North Carolina, Pennsylvania, South Carolina, Tennessee, Texas, Virginia, and West Virginia).
} 
facility construction, transportation, telecommunications, several types of infrastructure services, and taxes and tax incentives.

Understanding that businesses in different industries face different costs, KPMG calculates costs of doing business for sample industries (as the three tax-related studies and the TAIM approach did) at the city level. ${ }^{17}$ This study also assumes that an industry is composed of one or more business operations. For example, the agri-food industry is represented by food processing operations, and the auto parts industry consists of three operations: metal components (75 percent), plastic components (15 percent), and electronic subassemblies (10 percent). In addition, it standardizes the requirements of cost factors in each operation, which makes it much easier to do cost comparisons across locations. But it still omits regulatory costs, non-wage compensation, and costs of materials, including business services.

As in the other studies reviewed, KPMG's cost-comparison model does not consider non-cost factors or factors that affect costs indirectly. It also fails to pay attention to dynamic behavior.

The report we reviewed compares eight cities in the southeast region: Atlanta (GA), Dothan (AL), Greenville-Spartanburg (SC), Jackson (MS), Nashville (TN), Raleigh (NC), San Juan (PR), and Tampa (FL). According to the study's cost-comparison results, business costs in Atlanta, Raleigh, and Tampa are the highest among these cities. But if other non-cost factors - such as quality of life, market size, and agglomeration economies - and dynamic patterns were fully considered, the rankings would invariably change. As we know, in terms of firm formation and investment, those three cities are among the fastest growing in the United States.

\subsection{Other Studies}

Economic developers use other resources besides cost-of-doing-business studies to compare the competitiveness of their jurisdictions. We identified three in our e-mail survey: the Economic Strength Ranking, by POLICOM; the Best Performing Cities: Where America's Jobs Are Created, by DeVol and Fogelbach at the Milken Institute; and the ACCRA Cost-of-Living Index, by ACCRA. We will review each very briefly.

The first two studies focus on economic growth or performance of MSAs rather than on business costs. In measuring the "economic strength" of 318 MSAs, the POLICOM

\footnotetext{
${ }^{17}$ It uses 12 standard business operations: seven operations in the manufacturing sector, two operations in the R\&D sector, two operations in the software services sector, and one operation in the corporate services sector. The business operations in the manufacturing sector are (1) metal components, (2) plastic products, (3) food processing, (4) electronics assembly, (5) precision components, (6) pharmaceuticals, and (7) specialty chemicals. The operations in the R\&D sector are (1) biomedical R\&D and (2) electronic systems development and testing. The operations in the software services sector are (1) advanced software and (2) content development. The operation in the corporate services sector is shared services center.
} 
study considers the average annual growth rate and the average annual deviation for 18 categories $^{18}$ for two different time periods, the 15-year term from 1976 through 1990 and the 10-year term from 1991 through 2000. According to its formulas, the area with consistent growth is rated higher than the area with less consistent growth. ${ }^{19}$

The Milken Institute's Best Performing Cities Index, used in DeVol and Fogelbach's study, is an "outcome-based measure," which includes job, wage, and salary growth and technology output growth over the most recent five years and the latest year's performance in MSAs. It also includes the latest 12-month job growth performance (DeVol and Fogelbach 2003). Employment growth is given the highest weight (0.429), and wage and salary growth and technology output growth are weighted 0.286 and 0.285 , respectively.

The ACCRA Cost-of-Living Index is commonly used in comparing living costs across MSAs; it does not incorporate information on the cost of doing business. Instead it provides information on "relative differences among urban areas in the cost of consumer goods and services appropriate for professional and managerial households in the top income quintile" (ACCRA 2003). The index divides consumer spending into six categories, weighted as follows: grocery items (0.14), housing (0.29), utilities (0.10), transportation (0.10), health care (0.04), and miscellaneous goods and services $(0.33)$.

\subsection{Summary}

Table 4 summarizes much of the preceding discussion about the seven cost-of-doingbusiness studies, as well as the best example of a self-produced study. They are by no means the only ones used by economic developers, but they represent the range of studies that exist. The self-produced example in the table assumes that the analyst understands the determinants of business location and amasses all available cost and non-cost (or indirectly related to cost) data.

Even the best studies do not represent costs of doing business accurately. They suffer from what statisticians call "omitted variable bias." They do not capture all costs (for

\footnotetext{
${ }^{18}$ They are per capita personal income; earnings—all workers; employment—all workers; annual earnings per worker; wage \& salaried workers-earnings; wage \& salaried workersemployment; wages \& salaried workers—annual earnings per; nonfarm proprietors—earnings; nonfarm proprietors-number of; nonfarm proprietors - annual earnings per; retail tradeearnings; retail trade-employment; retail trade-annual earnings per worker; constructionearnings; construction—employment; construction—annual earnings per worker; medical transfers to the poor (medicaid); and income maintenance (welfare).

${ }^{19}$ The formulas for economic strengths in MSAs are as follows (from POLICOM's Website, www.policom/methodol.htm): "The average deviation from previous year (DEV) and the average annual increase (AAI) were calculated for each category for each time period. The DEV was subtracted from the AAI to create a strength factor for each category. Each category was adjusted to give each equal weight. The data for both the 15-year and 10-year terms were totaled for each of the categories. The total for the 10-year terms was doubled (giving the last ten years twice the emphasis of the previous fifteen years) and added to the total for the 15-year term.”
} 
TABLE 4

Scorecard for Different Approaches in Determining Cost-of-Doing-Business

\begin{tabular}{lccccc}
\hline & $\begin{array}{c}\text { Comprehensive } \\
\text { List of Costs }\end{array}$ & $\begin{array}{c}\text { Inclusion of Non-Cost } \\
\text { and Indirect Cost } \\
\text { Factors }\end{array}$ & $\begin{array}{c}\text { Feedback and } \\
\text { Adjustment Effects }\end{array}$ & $\begin{array}{c}\text { Stepped Down } \\
\text { to Local Level }\end{array}$ & $\begin{array}{c}\text { Inter-Industry } \\
\text { Differences }\end{array}$ \\
\hline $\begin{array}{l}\text { Ernst \& Young } \\
\text { W.V. Dept. of Tax \& }\end{array}$ & 1 & 0 & 0 & 1 & 3 \\
$\quad \begin{array}{l}\text { Revenue and W.V. } \\
\text { Development Office }\end{array}$ & 1 & 0 & 0 & 1 & 3 \\
$\begin{array}{l}\text { Pennsylvania Economy } \\
\quad \text { League }\end{array}$ & 1 & & 0 & 1 & 0 \\
$\begin{array}{l}\text { Economy.com } \\
\text { Fisher and Peters }\end{array}$ & 2 & 0 & 0 & 1 & 0 \\
Economist Intelligence & 2 & 0 & 0 & 3 & 3 \\
$\quad$ Unit & 2.5 & 2 & 0 & 0 & 0 \\
KPMG & 2 & 2 & 0 & 3 & 3 \\
Self-Produced & 2.5 & 2 & 0 & 3 & 3 \\
\hline Scoring system: $0-3$, with 0 being the worst and 3 the best. The authors' judgment. & & \\
\hline
\end{tabular}


example, non-wage compensation and regulatory compliance), because primary data collection is normally considered too expensive and secondary data for them simply do not exist. And for similar reasons, they leave out location determinants arising from agglomeration economies, quality-of-life factors, and special amenities, among others. Finally, even the very best examples do not account for compensating differentials and changes in behavior in response to higher costs that may discourage mobility. The inclusion of those dynamic effects requires sophisticated modeling that is beyond the capacity of local and state officials, consulting firms, and even many university-based researchers. Even the best-intentioned and sophisticated attempts to capture the cost of doing business are likely to misrepresent the truth.

Even more troubling is the widespread use of partial studies (focusing on tax rate and incentive differences alone, or broad indices at the state or national level) as a way to attract business or affect policy. It is hard to understand what real use such studies as the ones produced by Ernst \& Young, Pennsylvania Economy League, Economy.com, and Economics Intelligence Unit, have in either recruitment or policy-making.

There are two levels of differences among states. At the macro-level there is a considerable cost and service gap between states like California, Massachusetts, and Connecticut on the one hand, and Mississippi and Alabama on the other. Taxes, energy, and labor costs are clearly higher in the more highly developed group of states. At the same time, those states tend to provide a higher level of services and amenities. We do not even need to conduct an analysis to understand those differences. There are much smaller differences among states within the same region, at the same general level of economic development, which compete against each other for similar types of businesses. Economy.com's cost-of-doing-business indexes are 94.7 for North Carolina, 95.8 for South Carolina, 97.2 for Virginia, 93.8 for Tennessee, and 95.3 for Georgia. These rankings are so close so as to not to be very helpful. They undoubtedly are subject to measurement error and omitted variable bias. Moreover, the scores are not useful for ranking cities within those states, which are of greater interest to businesses seeking to relocate or expand.

\section{CONCLUSION}

Sometimes we observe disjunctions between analysis and practice. This paper addresses one of them: the widespread use of cost-of-doing-business studies for two competing purposes, which is hard to defend for either application. We have demonstrated that even the best-conceived and best-executed studies are incapable of ranking alternative locations accurately, especially those that are at roughly the same level of economic development. The data requirements and analytic challenges to do those studies correctly are beyond the scope of the expert community. And, the closer policy analysts come to doing it correctly, the less timely the results are and the harder they are for the lay public (decision makers included) to comprehend. 
This is the first head-on critique of cost-of-doing business studies. But the general thrust of the paper is not new. In a study parallel to this one, Fisher (2005) asks whether the five indexes commonly used by public officials and policy makers to measure the capacity or potential for economic growth in states and cities are proper indicators of their business climate. ${ }^{20}$ It is an important issue, according to Fisher, because jurisdictions tend to use those indexes to justify tax cuts and regulatory reform to increase business investment and job creation. He applies the following criteria to each of the measures: (1) whether all (and only) relevant variables are included in the index, (2) whether the variables employed measure correctly what they claim to measure, (3) whether disparate components are correctly combined into a single index, (4) whether the weighting system is correct and appropriate in combining disparate components, and (5) whether the index has been a good predictor of economic growth in states and cities over time. Like us, Fisher concludes that the data and methods employed in constructing state-local competitive indexes are incorrect and incomplete, thus their results are misleading. For example, the five indexes are not consistent in ranking states in terms of business climate or competitiveness. Forty-five states appear in the top 20 in at least one of the five indexes. Moreover, business interests can easily use these indexes to justify cutting business taxes in their states, since they can find at least one index that puts their states in the bottom half of all states in terms of heavy business taxes.

Which brings us back to the puzzle with which we began this paper: what accounts for the misuse of devices to help recruit industry and to convince legislators to change policy? Buffalo hunting has become more and more difficult in the United States, as the herd has thinned and more grazing grounds have opened around the world. Economic developers who see recruitment as the path to prosperity are increasingly desperate to demonstrate competitive advantage for their region, even if none exists, and to increase competitive advantage by convincing legislators that their state is falling woefully behind the competition. They may use their own comparisons or those produced by outside experts, but in either case they use cost-of-doing-business studies as a marketing tool. And the complexities of the task, as we have demonstrated, give them latitude to craft their messages to their advantage. The sad truth is that no one can do better, so the size of the bias in their analysis is not likely to be scrutinized. It is important to stress here that economic developers do not necessarily have bad intentions. Many believe that the messages they are crafting are true. But as the saying goes, the road to hell is paved with good intentions.

Is there blame to be assigned? Are the economic developers acting irrationally to create competitive advantage for their states or cities? Yes and no. They are paid to

\footnotetext{
${ }^{20}$ The five indexes of competitiveness that Fisher (2005) reviews are (1) the "Small Business Survival Index," by the Small Business and Entrepreneurship Council; (2) the "State Business Tax Climate Index," by the Tax Foundation; (3) the "Metro Area and State Competitiveness Report," by the Beacon Hill Institute; (4) the "Fiscal Policy Report Card on America's Governors," by the Cato Institute; and (5) the "Economic Freedom Index," published by the Pacific Research Institute in 2004. The first three indexes are produced annually, and the fourth index is produced biennially.
} 
promote their jurisdictions. But with global competition and perpetual budget crises, we cannot afford destructive competition. Nothing is wrong with lobbying for improvements in business climate or in the level of infrastructure and services. But it is irresponsible to push spotty data and partial analysis too far. A "race to the bottom" makes everyone worse off. As Rubin (1990) points out, it is hard for economic developers to take a broader view in promoting economic development, especially when economic circumstances in their communities become more turbulent. But it is important for economic developers to take just such a view and to be more circumspect about the limitations of the data and analysis they employ.

Consultants are also at fault to the extent that they sell a product without full disclosure of its limitations. Just as cigarette producers are required to use warning labels that cigarettes can be harmful to one's health, those who produce cost-of-doing-business studies need to disclaim them as truthful rankings of places' competitiveness. That can be dangerous to the fiscal health of cities and states. Moreover, shoddy analysis, analysis that is clearly self-serving, or well-intentioned analysis that is pushed beyond the limits of the data and methods available reflect poorly on what we are all about: speaking truth to power. Gresham's Law applies to the economic development policy world, as it does to the world of money: bad analysis forces out good analysis, so everyone is poorer.

Finally, if accurate and useful cost-of-doing-business studies are not likely to be produced given time, data, and other resource limitations, should we not accept the product we get instead? The quick answer is yes. Location decisions would be made no less efficiently in the absence of the studies, and society as a whole would save the considerable resources that are used to produce them.

But logic does not always prevail. Despite the compelling case we have made in this article, the economic development world will continue to be inundated with cost-ofdoing-business studies. The expert community then needs to play several roles. First, we need to serve as a watchdog, to ensure that partial, poorly done, and misleading studies and reports are not taken seriously by decision makers. Second, we need to push for the assembly and maintenance of more complete local databases. (The IEDC effort is a promising start in that direction, but it is proprietary.) Third, we should continue to refine our partial equilibrium analyses of specific location factors so that decision makers have at least an order-of-magnitude sense of how businesses respond to specific elements of policy.

\section{REFERENCES}

ACCRA, 2003. ACCRA Cost-of-Living Index: Manual (March). Arlington, VA.

Bartik, T.J., 1985. "Business Location Decisions in the United States: Estimates of the Effects of Unionization, Taxes, and Other Characteristics of States,” Journal of Business and Economic Statistics 3(1), 14-22.

1994. "Better Evaluation Is Needed for Economic Development Programs to

Thrive,” Economic Development Quarterly 8(2), 99-106. 
2005. "Solving the Problems of Economic Development Incentives'” Growth and Change 36(2), 139-166.

Blair, J.P. and R. Premus, 1993. "Location and Space Theories” in Richard D. Bingham and Robert Mier (eds.), Theories of Local Economic Development. Sage Publications: Newbury Park, CA.

Bradbury, K.L., Y.K. Kodrzycki, and R. Tannenwald, 1997. "The Effects of State and Local Public Policies on Economic Development: An Overview," New England Economic Review (March/April), 1-12.

Census Bureau, 2003. "Statistics for Industry Groups and Industries: 2001” in Annual Survey of Manufactures (ASM) (January). Department of Commerce: Washington, D.C.

Carlton, D.W., 1983. "The Location and Employment Choices of New Firms: An Econometric Model with Discrete and Continuous Endogenous Variables” Review of Economics and Statistics 65(3), 440-449.

Curliss, J.A., 2005. "Bill Would Detail Incentives after the Fact," News \& Observer (Raleigh, NC), March 5, p. 1.

Carod, J.M.A., 2002. "Determinants of Industrial Location: An Application for Catalan Municipalities," Fundación de Estudios de Economia Aplicada EEE138 (May).. Available at www.fedea.es/hojas/publicado.html, September 5, 2003.

Connaughton, J.E. and R.A. Madsen, 2001. "Assessment of Economic Impact Studies: The Case of BMW and Mercedes-Benz," Review of Regional Studies 31(3), 293-303.

Coughlin, C.C., J.V. Terza, and V. Arromdee, 1991. "State Characters and the Location of Foreign Direct Investment within the United States," Review of Economics and Statistics 73(4), 675-683.

Coughlin, C.C. and E. Segev, 2000, "Location Determinants of New Foreign-Owned Manufacturing Plants,” Journal of Regional Science 40(2), 323-351.

DeVol, R.C. and F. Fogelbach, 2003. Best Performing Cities: Where America's Jobs Are Created (June). Milken Institute: Santa Monica, CA.

Dewar, M.E. 1998, "Why State and Local Economic Development Programs Cause So Little Economic Development,” Economic Development Quarterly 12(1), 68-87.

Duncan, H., 1992. "Interstate Tax Competition: The Good, the Bad, and the Ugly,” State Tax Notes (August 24), 266.

Economic Intelligence Unit, 2001. Worldwide Business Cost Comparisons: The Cost of Setting Up Business in 31 Countries (December). Research Report: London, UK.

Economy.com, 2003. United States Business Cost Review 2003 ( $9^{\text {th }}$ ed.). West Chester, PA.

Ernst \& Young, 2001. State of North Carolina Comparative Incentives Studies (July).

Fisher, P.S., 2005. Grading Places: What Do the Business Climate Rankings Really Tell Us? Economic Policy Institute: Washington, D.C.

Fisher, P.S. and A.H. Peters, 1996. Industrial Incentives: Competition Among American States and Cities. W.E. Upjohn Institute for Employment Research: Kalamazoo, MI.

1999. "Tax and Incentive Model Analysis of Ohio Economic Development Programs," in An Assessment of the Costs, Benefits, and Overall Impacts of the State of Ohio's Economic Development Programs (May 28). Cleveland State University Urban Center: Cleveland, $\mathrm{OH}$. 
Fisher, R.C., 1997. "The Effects of State and Local Public Services on Economic Development," New England Economic Review (March/April), 53-82.

Florida, R., 2002. The Rise of the Creative Class: And How It's Transforming Work, Leisure, Community and Everyday Life. Basic Books: New York.

Gabe, T.M. and K.P. Bell, 2004. "Tradeoffs Between Local Taxes and Government Spending as Determinants of Business Location,” Journal of Regional Science 44(1), 21-41.

Glaeser, E.L., 2001. “The Economics of Location-Based Tax Incentives.” Harvard Institute of Economic Research Discussion Paper 1932: Cambridge, MA.

Gordon, I.R. and P. McCann, 2000. "Industrial Clusters: Complexes, Agglomeration and/or Social Networks?” Urban Studies 37(3), 513-532.

Gottlieb, P.D., 1994. "Amenities as an Economic Development Tool: Is There Enough Evidence?” Economic Development Quarterly 8(3), 270-285.

Gray, W.B., 1997. "Manufacturing Plant Location: Does State Pollution Regulation Matter?” National Bureau of Economic Research (CES 97-8) (July): Washington, D.C.

Greenstone, M. and E. Moretti, 2003. "Bidding for Industrial Plants: Does Winning A 'Million Dollar Plant' Increase Welfare?” National Bureau of Economic Research Working Paper Series 9844 (July): Washington, D.C.

Hines, J.R., 1996. "Altered States: Taxes and the Location of Foreign Direct Investment in America,” American Economic Review 86(5), 1076-1094.

Holmes, M.R. and E. McCallum, 1993. "Economic Impact analysis of the MercedesBenz A.G. Multipurpose Vehicle Production Facility for the State of Alabama: Technical Report," Troy State University, Center for Business and Economic Services: Troy, AL.

Jaffe, A.B., S.R. Peterson, P.R. Portney, and R.N Stavins, 1995. "Environmental Regulation and the Competitiveness of U.S. Manufacturing: What Does the Evidence Tell Us?” Journal of Economic Literature 33(1), 132-163.

Jeppesen, T., J.A. List, and H. Folmer, 2002. "Environmental Regulations and New Plant Location Decisions: Evidence from a Meta-Analysis," Journal of Regional Science 42(1), 19-49.

Jarboe, K.P., 2001. "Knowledge Management as an Economic Development Strategy," Review of Economic Development (April). Economic Development Administration (EDA) Reviews of Economic Development Literature and Practice No. 7:

Johnson, J.D. and R. Rasker, 1995. "The Role of Economic and Quality-of-Life Values in Rural Business Location,” Journal of Rural Studies 11(4), 405-416.

KPMG, 2004. Competitive Alternatives International Report. www.competitive alternatives.com/report/default.asp, (April 13, 2003).

Levy, J.M., 1990. Economic Development Programs for Cities, Counties and Towns (2nd ed.). Praeger: New York.

Love, L.L. and J.L. Crompton, 1999. "The Role of Quality-of-Life in Business (Re)Location Decisions,” Journal of Business Research 44(3), 211-222.

Luger, M.I., 1996. "Quality-of-Life Differences and Urban and Regional Outcomes: A Review,” Housing Policy Debate 7(4), 749-771. 
Luger, M.I. and S. Bae, 2002. "Reconceiving the Role of Infrastructure in Production: A Focus on Regional and Industrial Differences,” presented at the $49^{\text {th }}$ Annual North American Meetings of the Regional Science Association International: Puerto Rico. , 2005. "The Effectiveness of State Business Tax Incentive Program: The Case of North Carolina,” Economic Development Quarterly 19(4), 327-345.

Luger, M.I. and W. Evans, 1988. "Geographic Differences in Production Technology," Regional Science and Urban Economics 18(3), 481-503.

Luger, M.I. and S. Shetty, 1985. "Determinants of Foreign Plant Start-Ups in the United States: Lessons for Policymakers in the Southeast," Vanderbilt Journal of Transnational Law (18), 223-245.

Luger, M.I. and K. Temkin, 2000. Red Tape and Housing Costs: How Regulation Affects New Residential Development, Center for Urban Policy Research, Rutgers, State University of New Jersey: New Brunswick, NJ.

Mani, M., S. Pargal, and M. Huq, 1996. "Does Environmental Regulation Matter? Determinants of the Location of New Manufacturing Plants in India in 1994" (November). World Bank.

Martinez, A., "Deals to Bring in Jobs Can Make Consultants Rich," News \& Observer (Raleigh, NC), August 7, 2005.

Moriarty, B.M., 1980. "Locational Trends in Manufacturing," in Industrial Location and Community Development. University of North Carolina Press: Chapel Hill, NC.

North Carolina Department of Revenue, 2002. North Carolina County Property Tax Rates For the Last Five Years. Raleigh, NC.

Papke, L.E., 1991. "Interstate Business Tax Differentials and New Firm Location," Journal of Public Economics 45(1), 47-68.

Pennsylvania Economy League, 2001. A Comparative Analysis of Major State Business Taxes in Pennsylvania and Other States (June).

POLICOM Corporation, 2001. Community Business Incentives Survey (April). Jupiter, FL.

POLICOM Corporation, 2003. Economic Strength Ranking. www.policom.com/ ranknum.htm (April 15).

Porter, M.E., 2000. "Location, Competition, and Economic Development: Local Clusters in a Global Economy,” Economic Development Quarterly 14(1), 15-34.

Renault, C.S., 2003. "Increasing University Technology Productivity: Understanding Influences on Faculty Entrepreneurial Behavior." PhD dissertation, University of North Carolina at Chapel Hill.

Reese, L.A. and R.A. Rosenfeld, 2001. "Yes, But...: Questioning the Conventional Wisdom about Economic Development," Economic Development Quarterly 15(4), 299-312.

Rich, S.M., 1997. “Commentary on the Significance of 'Quality-of-Life,”' in Richard D. Bingham and Robert Mier (eds.), Dilemmas of Urban Economic Development: Issues in Theory and Practice. Sage Publications: Thousand Oaks, CA.

Rubin, H.J., 1988. "Shoot Anything that Flies; Claim Anything that Falls: Conversations with Economic Development Practitioners,” Economic Development Quarterly 2(3), 236-251. 
1990. "Working in a Turbulent Environment: Perspectives of Economic Development Practitioners,” Economic Development Quarterly 4(2), 113-127.

Schmenner, R.W., 1982. "Making Better Capacity and Location Decisions: Advice to Manufacturers," in Making Business Location Decisions. Prentice-Hall: Englewood Cliffs, NJ.

Schmenner,R.W., J.C. Huber, and R.L. Cook, 1987. "Geographic Differences and the Location of New Manufacturing Facilities," Journal of Urban Economics 21, 83-104.

Schweke, W., C. Rist, and B. Dabson, 1994. Bidding for Business: Are Cities and States Selling Themselves Short? Corporation for Enterprise Development: Washington, D.C.

Segedy, J.A., 1997. “How Important Is ‘Quality-of-Life’ in Location Decisions and Local Economic Development?” in Richard D. Bingham and Robert Mier (eds.), Dilemmas of Urban Economic Development: Issues in Theory and Practice. Sage Publications: Thousand Oaks, CA.

South Carolina State Development Board, 1992. "Economic Impact Analysis of the BMW Project for South Carolina," Division of Research and Communications: Columbia, S.C.

Tannenwald, R. 1997. "State Regulatory Policy and Economic Development," New England Economic Review (March/April), 83-99.

Tiebout, C.M., 1956. “A Pure Theory of Local Expenditures,” Journal of Political Economy 64(5), 416-424.

Webber, M.M. and H.W.J. Rittel, 1973. "Dilemmas in a General Theory of Planning," Policy Sciences 4(2), 155-169.

West Virginia Department of Tax and Revenue and West Virginia Development Office, 2002. Analysis and Recommendations for West Virginia Tax Incentives (January 9).

Wildavsky, A.B., 1979. Speaking Truth to Power: The Art and Craft of Policy Analysis. Little Brown: Boston, MA.

Yates, E. and J.F. Burton, Jr., 2004. “Workers’ Compensation Insurance Industry Returns to Profitability in 2003,” Workers' Compensation Policy Review 4(5), 3-9.

\section{APPENDIX. NCEDA Survey}

Dear Economic Development Practitioners:

The Carolina Center for Competitive Economies (C3E), housed within the Kenan Institute of Private Enterprise, UNC-Chapel Hill, is studying the ways that economic developers evaluate their area's "cost of doing business" relative to other places.

Please help us understand how you make comparative judgments about your jurisdiction's costs of doing business vs. other places. The following questions will take only a few minutes to answer. You will get a copy of the full results, which should be useful to you. 
How important is each of the following information sources to you? Please rate each item on a scale from 1 to 5, 1 being the most important to your assessment of your relative cost of doing business:

Your own research and number-crunching [please fill in a \# from 1 to 5]

o What data sources do you rely on most for making comparisons?

Information about the costs of your and other locations that you learn from siteselection consultants or business executives during the selection process [please fill in a \# from 1 to 5]

$>$ Information about cost factors that you get in "de-briefings" from site-selection consultants or business executives after the site location decision is made [please fill in a \# from 1 to 5]

$>$ Written reports or studies with data on place-specific cost comparisons [please fill in a \# from 1 to 5]

o Please list the names/authors of reports you think are accurate, particularly well done or helpful to you, and why you think highly of them

o Please list any such reports that you did not find to be accurate or helpful, and why

Please e-mail this form to my associate, Suho Bae, at bae@email.unc.edu or fax to him at (919) 962 - 8202. Suho can be reached at (919) 843-2030.

Thank you for your input,

Sincerely,

Michael I. Luger, Professor of Public Policy, Business, and Planning, and

Director, Carolina Center for Competitive Economies (C3E) 